Nordic Journal of Modern Language Methodology

NJMLM

\title{
Om referat av tale og tanker. Innspill til grammatikk- og språkferdighets- undervisningen i tysk på universitets- og høgskolenivå.
}

\author{
Kåre Solfjeld ${ }^{\mathrm{a}}$ \\ a Høgskolen i Østfold
}

\begin{abstract}
This article presents aspects of reported speech in modern German from a contrastive Norwegian-German perspective. It focuses in particular on the use of indicative mood in German indirect reported speech and suggests topics which should be thematised when teaching German reported speech at university level.
\end{abstract}

\section{Innledning og ramme}

I grammatikk- og språkferdighetsundervisningen i tysk på norske universiteter og høgskoler gis det alltid en grunnleggende innføring i referatkonjunktiv. Dette temaet, som kanskje ikke behøver altfor mye plass i tyskundervisningen i skoleverket, fortjener absolutt oppmerksomhet på universitets- og høgskolenivå. I denne artikkelen er referatkonjunktiv også ett av temaene. Men først og fremst vil jeg rette oppmerksomheten mot en del andre aspekter ved referat av tale og tanker i moderne tysk, sammenligne med norsk, og diskutere hvilke perspektiver som kan (og kanskje bør) være med når temaet referat presenteres i tyskundervisning på avansert nivå med norske morsmålsbrukere som primærmålgruppe.

Hovedfokus er indirekte tale. I motsetning til et sitat hvor det en person har sagt, (i hvert fall i prinsippet) gjengis ordrett, 'de dicto', , refererer man ved indirekte tale ut fra eget perspektiv, det vil si at man i større grad gjengir 'de re': Innholdet refereres uten at man forplikter seg til ordrett gjengivelse; se Zifonun et al. (1997:1755f). Det betyr at uttrykk som

\footnotetext{
${ }^{1}$ Dette er på mange måter en forenkling, se for eksempel Pütz (1989:186).
} 
forankres i talesituasjonen: person, steds- og tidsdeiktiske uttrykk, i indirekte tale i stor grad velges ut fra den refererendes perspektiv (se for eksempel Kaufmann 1976:35f, FabriciusHansen 1989:162f, Zifonun et al. 1997:1761, Faarlund et al. 1997:978). I setningsparet nedenfor er 1a eksempel på sitat, på trykk ofte markert ved anførselstegn. 1b er indirekte tale. Det som ble sagt, gjengis på et senere tidspunkt, og presensformen er byttet ut med en preteritumform - ut fra den refererendes fortidsperspektiv.

(1a) Weil er sagte: "Ich habe kein Geld", ...

(1b) Weil er sagte, dass er kein Geld hatte, ... (Die Zeit/Zeit online, 11.6.2009, lest på nettet 6.5.2013) $)^{2}$.

Setningen i (1b) er et eksempel på det vi kan kalle prototypisk indirekte tale. Det refererte gjengis i en setning som er syntaktisk underordnet et utsagnsverb (sagte). Det refereres tale i snever forstand, dvs. hørbare ytringer. I denne artikkelen ser jeg imidlertid også på indirekte tale i videre forstand, ikke-prototypisk indirekte tale, for eksempel referat av tanker, observasjoner og sanseinntrykk - noe som ikke er tilgjengelig for andre på samme måte som tale og skrift, men som også kan refereres som en slags indirekte tale, og som også er interessant fra kontrastivt norsk-tysk perspektiv. Se Roncador (1988) og FabriciusHansen (2002) for en grundigere beskrivelse av indirekte tale som et graduelt fenomen. Setning 2 er eksempel på ikke-prototypisk indirekte tale, hvor det ikke gjengis noen hørbar ytring, men en frykt eller en urolig tanke:

(2) Ich [...] befürchtete, dass 'das' jetzt wieder losgeht. (Stettbacher 1990:84)

En annen form for indirekte tale som også er interessant fra kontrastivt tysk-norsk perspektiv, er såkalt 'berichtete Rede', hvor den indirekte talen har form av (sekvenser av) syntaktisk uavhengige setninger; se for eksempel Fabricius-Hansen (2009:523). Ved hjelp av referatkonjunktiven etableres et nivå ('Figuren-Ebene' med terminologien til FabriciusHansen 2009:531) som atskiller seg fra rammeteksten. Jfr. følgende eksempel hvor konjunktiven alene markerer referatfunksjonen entydig, og dermed at utsagnene har et annet opphav en forfatteren selv:

(3) Das war, wie meine Mutter letzthin, als ich nachfragte, berichtet hat, eine ganz normale Geburt. Die Mutter habe mich am Morgen um 7 Uhr bereits das erste Mal im Arm gehalten, aber leider nicht stillen können, weil ich einen heftigen Schluckauf gehabt habe. Nach Medikamentengabe sei ich mit der Zeit ruhiger geworden, und sie habe mich stillen können. Das sei leider nur eine Woche lang möglich gewesen, da sie anschließend an einer Brustentzündung gelitten habe. (Stettbacher 1990:86)

Ut fra denne vide rammen presenteres i det følgende aspekter ved indirekte referat i tysk ut fra didaktisk perspektiv - med tysk som målspråk og norsk som kontrastspråk - under følgende fire overskrifter: 1) systemforskjeller norsk-tysk, 2) et nærmere blikk på indikativ i

\footnotetext{
${ }^{2}$ Eksemplet er funnet ved søk i Das Digitale Wörterbuch der deutschen Sprache (DWDS); http://www.dwds.de.
} 
tyske referater, 3) om å gjengi sanseinntrykk, bevissthetsinnhold og tanker - mer om ikkeprototypiske indirekte referater og 4) om ubestemt perspektiv i indirekte tale.

\section{1) Systemforskjeller norsk-tysk}

Når man vil gjengi tale eller tanker som har funnet sted i fortiden, vil tempustransposisjon tempusforskyvning - være normalsystemet i norsk. I Faarlund et al. (1997:573) finner vi følgende beskrivelse og eksempler:

- Presens blir preteritum: Hun sa: "Jeg studerer språk" - Hun sa at hun studerte språk.

- Presens futurum (1.futurum) blir preteritum futurum (1. kondisjonalis): Hun tenkte: "Dette vil jeg gjøre" - Hun tenkte at dette ville hun gjøre.

- Preteritum blir preteritum perfektum (pluskvamperfektum): Knut sa: "Jeg kom forrige fredag" - Knut sa at han var kommet forrige fredag.

I det indirekte referatet blir tempus så å si valgt på nytt ut fra den refererendes fortidsperspektiv. Preteritum i den indirekte talen uttrykker dermed nåtid/samtidighet $\mathrm{i}$ forhold til den referertes nå, som vi med Fabricius-Hansen (2002:11) vil kalle 'figuralt nå', preteritum futurum uttrykker framtid i forhold til figuralt nå, og preteritum perfektum uttrykker fortid i relasjon til figuralt nå. Uforskjøvet presens vil på norsk normalt bare kunne brukes når det uttrykkes samtidighet også i forhold til den refererendes nåtid, som vi i det følgende vil kalle 'fortellernåtid'. I eksempel (4), hentet fra Faarlund et al. (1997:575), forutsettes det at vinduet fortsatt er knust når Pers utsagn refereres på et senere tidspunkt, dvs. ut fra fortellernåtiden:

\section{(4) Per sa at vinduet er knust}

Tempusforskyvning kan vi også finne i tysk når tale og tanker i fortiden gjengis. Jfr. eksemplene i (5) og (6). I (5) går preteritum indikativ i den indirekte talen tilbake på en presensform i tilsvarende direkte tale, og i (6) går preteritum perfektum indikativ i oversetningen tilbake på preteritum eller perfektum i en direkte gjengivelse av tankeinnholdet - anelsen:

(5) Er sprach aus [...], dass es im Grunde nur eine einzige Krankheit gab. (Lenz 1978:27) Tilsvarende direkte tale: "Es gibt im Grunde nur eine einzige Krankheit".

(6) Er ahnte dunkel, dass er sich auf ein Gebiet gewagt hatte, wo Vorsicht am Platz war. (Hackl 1987:10).

Tilsvarende direkte gjengivelse av tankeinnholdet: "Ich habe mich auf ein Gebiet gewagt, wo Vorsicht am Platz ist".

I tysk er dette systemet imidlertid langt fra enerådende. I tysk indirekte tale velges indikativiske tempusformer i stor grad også ut fra figural nåtid (jfr. Solfjeld 1983, 1989, Fabricius-Hansen 1989, 2002, 2003 og Ek 1996). Sagt på en annen måte 'overføres' tempus fra den direkte talen, observasjonen eller tanken uforskjøvet til referatet. Tempus i referatet blir dermed det samme som i et tilsvarende sitat, og den refererendes nåtid fortellertiden - forblir irrelevant for tempusvalget. Jfr. følgende eksempel: 
(7) Sie stand auf dem Pausenhof umringt von blonden Kindern, die sie komisch anguckten. Die Lehrerin sprach laut und langsam mit ihr, weil sie vielleicht dachte, dass das kurdische Mädchen sonst nichts versteht. Im Klassenzimmer setzte sie sich in die hinterste Bank, neben einen griechischen Jungen. (Potsdamer neueste Nachrichten, 20.11.2004, lest på nettet 3.5.2013)

I Zifonun et al (1997:1780) og Fabricius-Hansen (2009:531) blir uforskjøvet tempus sett på som normalsystemet ved indikativ $\mathrm{i}$ indirekte tale i tysk. "Erscheint in der abhängigen indirekten Rede der Indikativ, so werden im Normalfall die Tempora der direkten Rede gewählt" (Fabricius-Hansen 2009:531). Med figural forankring for tempusformene vil en presens- eller futurumform i tyske indirekte referater i stor grad kombineres med fortid i forhold til fortellernåtiden. Dette er ikke mulig, eller i det minste langt mindre vanlig i norsk.

\section{Et nærmere blikk på indikativ i tyske referater}

De ulike tidstolkningene for tyske indikativtempora og norske tempora i referater bør tyskkyndige på avansert nivå kjenne til. Når man leser tyske tekster hvor presens indikativ i referater helt klart er uten noen som helst relevans for det tidspunktet hvor referatet gjøres, vil en tilsvarende presensbruk i norsk i stor grad virke fremmed. De tyske tekstene vil nok i mange tilfeller inneholde kontekstuelle holdepunkter som gjør at tidsreferansene for den indirekte talen ikke utløser noen feiltolkning. Likevel er det viktig å kjenne til den utbredte bruken av figural temporal forankring for indikativtempora i indirekte tale i tysk - for å tolke tidsrelasjonene riktig. Og skal man bruke sine tyskstudier som basis for profesjonell oversettervirksomhet, er dette nødvendig kunnskap. De tre små tekstutsnittene i 8, 9 og10 er hentet fra ulike tyske aviser ${ }^{3}$. De er narrative og gjengir hendelser i fortiden. De kursiverte verbformene i presens inngår i indirekte referater, som er syntaktisk underordnet verb som angir tale- eller tankeaktivitet (sagte, dachte).

(8) Am nächsten Morgen wurde er vom Telefonklingeln geweckt. Ein Hauptmann der Polizei sagte, dass er sich unverzüglich auf der Wache melden soll. Dort wurde Jacek Adler verhört, er sollte über sich und andere Homosexuelle berichten. (Berliner Zeitung 19.11.2005, lest på nettet 6.5.2013)

(9) Er startete ein Experiment - und revolutionierte die Presselandschaft. ... Der Tag, an dem Alan Rusbridger dachte, dass etwas gewaltig schief läuft, begann wie alle Tage in der Redaktion des "Guardian" mit der Konferenz um zehn Uhr. Es war der 9. April 1994, alles wie immer, bis am Ende ein Kollege erzählte, dass seine Tochter die letzte Nacht durchgeweint hatte. (Der Tagesspiegel, 1.11.2003, lest på nettet 6.5.2013)

(10) Ihre Mutter war es, die ihr dazu riet, sich zum Casting anzumelden. Erst habe ich gezögert, doch dann dachte ich, dass die Show eine gute Möglichkeit ist, um Aufmerksamkeit zu bekommen. Rebecca schaffte es unter die besten 40, bevor sie rausflog. (Die Zeit/Zeit online, 27.2.2007, lest på nettet 3.5.2013)

${ }^{3}$ Også disse eksemplene er funnet ved søk i Das Digitale Wörterbuch der deutschen Sprache; se fotnote 1. 
Vi ser at presenformene i disse referatene er omgitt av preteritumformer som klart etablerer en fortidskontekst, og det er ingen holdepunkter i teksten for at innholdet i referatene - det vil si presensformene - skulle være relevante for det tidspunktet hvor referatet gjøres, for fortellernåtiden. Her bør man ikke automatisk overføre de tyske presensformene til norsk presens, men heller i samsvar med norsk tempustransposisjon velge preteritum. Tilsvarende presensformer vil kanskje ikke oppfattes som feil i norsk (jfr. b-versjonene i oversettelsene nedenfor), men preteritum vil være mer flytende og korrekt (jfr. c-versjonene i oversettelsene nedenfor):

(8b) Neste morgen ble han vekket av at telefonen ringte. En politibetjent sa at han straks skal melde seg på politistasjonen. Der ble Jacek Adker forhørt ....

(8c) Neste morgen ble han vekket av at telefonen ringte. En politibetjent sa at han straks skulle melde seg på politistasjonen. Der ble Jacek Adker forhørt ....

(9a) Han startet et eksperiment og revolusjonerte presselandskapet. ... Den dagen hvor Alan Rusbridger tenkte at noe går alvorlig galt, begynte som alle andre dager i redaksjonen til The Guardian ...

(9b) Han startet et eksperiment og revolusjonerte presselandskapet. ... Den dagen hvor Alan Rusbridger tenkte at noe gikk/ville gå alvorlig galt, begynte som alle andre dager $\mathrm{i}$ redaksjonen til The Guardian ...

(10b) ... Først nølte jeg, men så tenkte jeg at showet er en god mulighet til å få oppmerksomhet. Rebecca klarte å komme blant de førti beste ...

(10c) ... Først nølte jeg, men så tenkte jeg at showet var/ville være en god mulighet til å få oppmerksomhet. Rebecca klarte å komme blant de førti beste ...

I tyskundervisning på relativt høyt nivå vil det være viktig å tematisere og illustrere at man i tysk indirekte tale i indikativ i motsetning til i norsk velger figuralt temporalt perspektiv. Det bør være en del av den reseptive språkkompetansen å kjenne systemet for tidsreferansen til presensformene i referater som i (8), (9) og (10). Det er også viktig å kjenne til at indikativ, og kanskje spesielt indikativ med figural temporal forankring, et et trekk ved muntlig preget tysk. I undervisning som inngår i utdannelsen av profesjonelle oversettere, fortjener temaet indikativformer med figural temporal forankring stor oppmerksomhet. Feiltolkinger av temporalt innhold eller stilistiske konnotasjoner kan lett føre til mindre adekvate oversettelser. I følgende eksempler fra publiserte oversettelser er tysk presens i indirekte referater erstattet med preteritum i norsk, fordi de tyske presenformene er uten relevans for fortellernåtiden. Dette synes å gi mer vellykkede oversettelser enn om oversetterne hadde brukt presens i de norske versjonene.

(11a) War niemand bei dir, der dir beigestanden hätte und gesagt hätte, auf was es ankommt? (Stettbacher 1990:87)

(11b) Var det ingen som sto hos deg og sa hva du skulle gjøre? (Stettbacher, norsk oversettelse, 1993:86)

(12a) Anselmo Rodriguez fragte nach einer Weile, ob noch andere Gründe, handgreiflichere, vorliegen. (Hackl:1987:17) 
(12b) Anselmo Rodriguez spurte etter en stund om det ikke forelå andre, mer håndgripelige grunner. (Hackl, norsk oversettelse, 1988:16)

(13a) Ich [...] befürchtete, dass 'das' jetzt wieder losgeht. (Stettbacher 1990:84)

(13b) Jeg [...] var redd for at 'det' skulle ta fatt på ny. (Stettbacher, norsk oversettelse, 1993:83)

I undervisningen kan det være spesielt viktig å se på bruken av uforskjøvet indikativ i indirekte tale i selvstendige setninger i tysk. I det følgende tekstutsnittet (14a) bidrar indikativformer med figural temporal forankring til at de selvstendige setningene oppfattes som referat. Det kan imidlertid diskuteres om det her dreier seg om overgang til grafisk umarkert direkte tale, eller om det foreligger en slags 'berichtete Rede' med uforskjøvet presens og presens perfektum indikativ. Det kan også diskuteres om presens- og presens perfektumformene brukes som middel til å oppnå en stilistisk effekt - en slags historisk presens. Her er ulike tolkningsmuligheter, som det er nødvendig å tematisere i undervisningen, ikke minst i undervisning som inngår i oversetterutdannelse. Ulike tolkninger kan munne ut i ulike oversettelser. I den autentiske norske oversettelsen (14b) er presens og presens perfektum forskjøvet til preteritum og preteritum perfektum. Det er følgelig nærliggende å tenke at oversetteren har oppfattet de presens- og presens perfektumformene som 'berichtete Rede' med uforskjøvet indikativ.

(14a) Von Frau Varela erfuhr sie, daß man eine neue Werft ihrer Bestimmung übergeben hatte, daß dem verstorbenen, liebenswerten Kanonikus ein jüngerer, schroffer gefolgt war, dass das Kasino wegen Baufälligkeit und das sozialistische Volksheim staatsgefährdender Agitation geschlossen worden waren und daß eine gewisse Frau Pelayo, sie erinnerte sich doch sicher?, plötzlich verstorben war. Man redet davon, daß ihr Mann nachgeholfen hat. Genaueres aber ist aus den Ärzten nicht herauszubekommen. (Hackl 1987:68)

(14b) Fru Varela fortalte at det var bygget et nytt verft, at elskelige avdøde Kanonikus hadde fått en yngre og barskere etterfølger, at kasinoet og det sosialistiske Folkets Hus var blitt stengt på grunn av henholdsvis dårlig forfatning og statsfiendtlig agitasjon, og at en viss fru Pelayo, hun husket vel henne? plutselig hadde dødd. Man snakket om at mannen hennes hadde vært innblandet. Mer fikk de ikke ut av legene. (Hackl, norsk oversettelse, 1988:61-62)

Omvendt kan det i visse tilfeller være naturlig å gjengi en norsk preteritumform med presens i en tysk oversettelse. Indikativ i indirekte tale, og ikke minst indikativ med figural temporal forankring, er typisk for en muntlig stiltone i tysk (jfr. Fabricius-Hansen 2009:532534; Zifonun et al. 1997:1768-1769 og Andersson 1994:39-40). Dermed kan det - av stilistiske årsaker, for å formidle et muntlig preg - være naturlig å erstatte en forskjøvet norsk preteritumform med presens; jfr. følgende autentiske eksempel med preteritum i den norske originalen og presens indikativ i den tyske oversettelsen:

(15a) Og så ville han at du skulle få hevne sønnen din ... (Holmås 1985:45) (15b) Und dann wollte er, dass du deinen Sohn rächen sollst. (Holmås, tysk oversettelse, 1988:36) 
Samtidig er det viktig å vite om variasjonsmulighetene i tysk. Tempustransposisjon forekommer ikke sjelden - også på tysk. Figural nåtid $i$ kombinasjon med fortid fra fortellerperspektiv kan dermed også uttrykkes ved indikativ preteritum. Jfr. (1) ovenfor og følgende setning (16) hvor preteritum indikativ i det indirekte referatet tilsvarer presens $\mathrm{i}$ direkte tale:

(16a) Er sprach aus, was vor und nach ihm kaum jemand auszusprechen wagte, nämlich, dass es im Grunde nur eine einzige Krankheit gab ... (Lenz 1978:27)

(16b) Tilsvarende direkte tale: ... Er sprach aus: "Es gibt im Grunde nur eine einzige Krankheit ...".

Kunnskap om tidstolkningen av indikativ i indirekte tale i tysk bør inngå i tyskkompetansen til tyskstudenter ved norske høgskoler og universiteter. Det er viktig å kjenne til de ulike mulighetene for å kunne tolke formenes tidsinnhold og stilistiske implikasjoner riktig, ikke minst for å kunne oversette indirekte tale adekvat mellom tysk og norsk.

\section{Om å gjengi sanseinntrykk, bevissthetsinnhold og tanker - mer om ikke- prototypiske indirekte referater}

Ut fra bruken av indikativtempora i såkalt 'erlebte Rede' i tysk ${ }^{4}$ - hvor det gjengis tanker og bevisshetsinnhold - er det nærliggende å anta at man i tysk bruker forskjøvede tempora også når tanker, bevissthetsinnhold etc. gjengis i andre syntaktiske sammenhenger. I 'erlebte Rede' brukes tempustransposisjon: tempusgruppe II, kombinert med würde-fomer for relativ framtid - med terminologien til Fabricius-Hansen (2009:524). 'Erlebte Rede' inngår normalt i narrative tekster i preteritum, og tempusbruken skiller seg dermed ikke fra den omliggende teksten. I Fabricius-Hansen (2009:524) finner vi følgende eksempel på 'erlebte Rede':

(17) Der Bäcker war schlechter Laune. Er musste jetzt wirklich der Tocher die Wahrheit erzählen. Es ging nicht an, dass sie in dem Alter an den Weihnachtsmann glaubte! Hoffentlich würde sie nicht allzu enttäuscht sein.

Når sanseinntrykk, bevissthetsinnhold og tanker gjengis i syntaktisk underordnet form, dvs. i leddsetninger som er syntaktisk underordnet verb som spüren, wissen, denken, brukes da også ofte indikativtempora i samsvar med systemet i 'erlebte Rede', og dermed samtidig i samsvar med det norske systemet tempustransposisjon. Men også figural temporal forankring synes å være relativt vanlig. I tysk brukes indikativtempora med figural temporal forankring følgelig ikke bare i indirekte tale i snever forstand, det vil si når hørbare eller

\footnotetext{
${ }^{4}$ Om erlebte Rede i tysk se også Zifonun (1997:1775), som bruker den mer logiske betegnelsen erlebtes Denken.
} 
lesbare ytringer og utsagn gjengis, men også når sanseinntrykk, tanker, bevissthetsinnhold etc. refereres. I den relevante litteraturen er det relativt lite informasjon om tempusbruken i denne typen ikke-prototypisk indirekte tale. For å få et visst inntrykk av fordelingen mellom figural temporal forankring på den ene siden og forankring i fortellertiden på den andre foretok vi et par søk i DWDS' aviskorpus ${ }^{5}$.

Første søk omfattet referater av sanseinntrykk i setninger med subjunksjonen dass etter verbet spüren i preteritum, tredje person singular, dvs. strukturer av typen:

(18) Nicht so Sinisa Mihajlovic. Es war in der 59. Minute der Partie Jugoslawien gegen Slowenien, da spürte Mihajlovic plötzlich, dass es Zeit ist zu gehen. Seine Mannschaft lag $0: 3$ gegen die Slowenen zurück; es konnte also nur noch besser werden.

(Berliner Zeitung, 15.6.2000, lest på nettet 15.3.2013)

Antallet indikativ presensformer med figural temporal forankring ble talt opp, dvs. indikativ presens brukt ved nåtid/framtid i relasjon til figuralt nå og entydig fortid i relasjon til fortellertiden (referattiden). Samtidig ble antall indikativ preteritumformer med forankring i fortellertiden talt opp, dvs. indikativ preteritum brukt ved den samme tidsrelasjonen: nåtid/framtid i relasjon til figuralt nå og fortid i relasjon til fortellertiden (referattiden). Slik ble forholdet mellom de to mulige uttrykkene for samme tidsrelasjon kartlagt. Ved spüren fant vi følgende fordeling:

Indikativ med figural forankring (presens): $\quad 57$ former (22\%) Indikativ med forankring i fortellertiden (tempusforskyvning, pret.): 202 former (78\%)

Et eksempel på presens og figural temporal forankring i forbindelse med spüren finner vi $\mathrm{i}$ (18) ovenfor og i (19):

(19) Es war seine letzte Oper. Er spürte, dass die Zeit über ihn hinweggeht. (Die Zeit, 3.6.2001, lest på nettet 15.3.2013)

Et eksempel på preteritum og temporal forankring i fortellertiden i forbindelse med spüren finner vi i (20):

(20) Die Frau, die deutsche Vorfahren hat, begann als Fünfjährige etwas unbeholfen mit Eishockey, spielte bis sie 14 Jahre alt war mit Jungen und Männern zusammen, wechselte dann zum Frauen-Eishockey, rückte 1994 in den Kader der kanadischen LacrosseMannschaft für die Commonwealth Spiele und machte noch zusätzlich Radsport und Inline-Skating. Doch dann spürte sie, dass sie im Eishockey nicht weiterkam. Sie suchte eine neue Herausforderung und fand den Eisschnelllauf. (Tagesspiegel, 6.3.2005, lest 21.5.2013)

Annet søk i det samme korpuset omfattet referat av bevissthetsinnhold i dass-setninger etter verbet wissen preteritum, tredje person singular, dvs. strukturer av typen:

\footnotetext{
${ }^{5}$ Det dreier seg om utgaver av avisene Berliner Zeitung, Zeit/Zeit online, Potsdamer neueste Nachrichten og Der Tagesspiegel. Om DWDS se fotnote 2.
} 
(21) Ich wusste nicht, dass in einem Hotel in Kigali hunderte Menschen versteckt wurden... (Potsdamer neueste Nachrichten, 19.3.2005, lest på nettet 3.5.2013)

I setninger som er syntaktisk underordnet wissen, hvor det altså dreier seg om å gjengi bevissthetsinnhold, finner vi følgende fordeling mellom de to mulige temporale perspektivene til uttrykk for figural nåtid/framtid og fortid i relasjon til fortellertiden:

Indikativ med figural forankring (presens):

99 former (34\%)

Indikativ med forankring i fortellertiden (tempusforskyvning, pret.): 192 former (66\%)

Et eksempel på presens og figural temporal figural forankring i forbindelse med wissen finner vi i (22):

(22) Sein Vater John Carradine hatte mit John Wayne den legendären Western Stagecoach gedreht, auch Davids Brüder Robert, Bruce und Keith wurden Schauspieler. Als Kind wusste ich gar nicht, dass mein Vater beim Film arbeitet. Ich dachte, er wäre Kapitän. (Die Zeit/Zeit online 11.6.2009, lest 19.3.2013)

Eksempler på temporal forankring i fortellertiden i i forbindelse med wissen finner vi i (21) ovenfor og i (23) og (24):

(23) Das war sein Glück und das war seine Last. Müller genoss sein Dasein als Wanderer zwischen den Welten, aber er wusste auch, dass seine ganze Arbeit abhing von dieser Position. Er war angewiesen auf den Fortbestand der DDR. (Berliner Zeitung, 31.12.2005, lest på nettet 21.5.2013)

(24) So etwas nagt am Selbstwertgefühl und ändert den Blick auf das ganze Leben. Ich wusste, dass er sehr qualifiziert war, und hatte damit nicht gerechnet. Aber das war 2002, die Arbeitsmarktsituation war sehr schlecht. (Die Zeit, 6.7.2009, lest på nettet 21.5.2013)

Et tredje søk i det samme materialet omfattet referat av tankeinnhold i dass-setniger etter verbet denken i preteritum, tredje person singular, dvs. strukturer av typen:

(25) In Istanbul konnte ich nicht mehr kreativ sein. Ich wurde paranoid und dachte, dass die Presse überall lauert. War es wirklich so schlimm? (Potsdamer neueste Nachrichten, 1.9.2004, lest på nettet 3.5.2013)

I setninger som er syntaktisk underordnet denken, hvor det altså dreier seg om mer aktiv kognitiv virksomhet, finner vi følgende fordeling mellom de to mulige temporale perspektivene til uttrykk for figural nåtid/framtid og fortid i relasjon til fortellertiden:

Indikativ med figural forankring (presens):

83 former $(75 \%)$

Indikativ med forankring i fortellertiden (tempusforskyvning, pret.): 28 former (25\%) 
Et eksempel på presens og figural temporal figural forankring i forbindelse med denken finner vi i (25) ovenfor og i (26) og (27):

(26) Wir kamen gar nicht so weit. Jeder dachte, dass nur sein Viertel brennt. Aber es brannte ja die ganze Stadt. (Potsdamer neueste Nachrichten, 12.2.2005, lest på nettet 3.5.2013).

(27) Sie stand auf dem Pausenhof umringt von blonden Kindern, die sie komisch anguckten. Die Lehrerin sprach laut und langsam mit ihr, weil sie vielleicht dachte, dass das kurdische Mädchen sonst nichts versteht. Im Klassenzimmer setzte sie sich in die hinterste Bank, neben einen griechischen Jungen. (Potsdamer neueste Nachrichten, 20.11.2004, lest på nettet 3.5.2013).

Et eksempel på temporal forankring i fortellertiden i forbindelse med denken finner vi i (28):

(28) Und er habe gespürt, dass die meisten Menschen keinen Unterschied machten zwischen Afghanistan und den Terroristen, die die USA angegriffen hatten. Vielleicht dachte Jürgen Todenhöfer auch, dass es ein guter Zeitpunkt war, mit dem Ruf als rechter Scharfmacher aufzuräumen, den inm seine politische Zeit eingetragen hatte. Todenhöfer begann zu schreiben, erst an US-Präsident Bush, schließlich für die FAZ. (Die Zeit/Zeit online, 2.4.2008, lest 3.5.2013)

Det skal presiseres at søkene (som tallene ovenfor viser) ikke var spesielt omfattende, og at det dessuten nødvendigvis måtte foretas en del valg: Verbet i oversetningen ble avgrenset til tredje person éntall, det ble brukt ny rettskrivning for wusste og dass, og dass måtte forekomme innenfor en sekvens på fem ord fra verbet i oversetningen. Det ble heller ikke gjort noe forsøk på å inkludere subjunksjonsløse undersetninger. Disse avgrensningene har selvsagt betydning for hvordan søkeresulatatene ble seende ut. Ved hvert søk kom det i de syntaktisk underordnede setningene (naturligvis) fram en del eksempler med würde-former, og - som ventet spesielt etter denken - konjunktivformer, det vil si belegg som falt utenfor rammen for denne undersøkelsen, men som det kan være interessant å se på i andre sammenhenger. Eksempler som det var vanskelig å tolke temporalt, ble heller ikke tatt med. Det skal videre presiseres at indikativ i opptellingen også omfattet såkalte modusambivalente former, for eksempel presens flertallsformer som lesen, og preteritumformer som spielte(n).

Selv om denne undersøkelsen har sine klare begrensninger, kan vi slå fast at de to systemene - figural forankring og forankring i fortellertiden - er representert i referater som omfatter hele spekteret fra sanseinntrykk via bevissthetsinnhold til mer aktiv tankevirksomhet. Andelen former med figural forankring er spesielt stor etter denken. Denne undersøkelsen tyder følgelig på at indikativ med figuralt perspektiv er vanlig også i ikke-prototypisk indirekte tale, og at fordelingen mellom figuralt perspektiv og fortellerperspektiv kanskje ikke er så ulik i prototypisk og ikke-prototypisk indirekte tale i tysk. Dette er innsikt som bør inngå i tyskundervisningen på høyere nivå - ikke minst i den undervisningen som tar sikte på å øke den reseptive språkkompetansen.

\section{Om ubestemt perspektiv $i$ indirekte tale}


Når indirekte tale opptrer i selvstendige setninger i tysk (berichtete Rede), vil konjunktivformer ofte markere entydig at det dreier seg om referat av noe andre har sagt, og dermed ikke skal tilskrives den referende; jfr. konjunktivformene i de selvstendige setningene i (3) ovenfor. I norsk, hvor vi ikke har den samme strukturmuligheten, vil det i selvstendige setninger som følger etter indirekte tale syntaktisk underordnet et utsagnsverb, til dels være vanskelig å avgjøre om referatet fortsetter i de selvstendige setningene, eller om det er den refererendes oppfatninger som gjengis. Jfr. den interessante og omfattende undersøkelsen i Vadøy (2008) omkring denne typen ubestemt perspektiv i pressetekster fra kontrastivt norsk-tysk perspektiv. I følgende tekstutsnitt, hentet fra Vadøy (2008:70), vil det for eksempel være uklart om den kursiverte setningen fortsetter referatet, eller om det er forfatterens perspektiv som overtar:

(29) NATO-talsmenn sier at det er et tegn på svakhet at Taliban nå nesten utelukkende utfører selvmordsattentater og bakholdsangrep. Taliban er ikke lenger $i$ stand til å utføre større angrep, slik det ble gjort for et år tilbake. (Dagsavisen 29.02.08)

I avistekster er det ofte viktig å formidle hvem som er kilden til et utsagn, noe konjunktivformene i tysk formidler entydig i de selvstendige setningene i følgende tekstutsnitt:

(30) Ihr Bruder Robert sagte jetzt, dass er immer zu ihr gehalten habe. Er sagte aber auch, dass das nicht immer leicht war. Zu extravagant seien die Ziele und Vorstellungen seiner Schwester gewesen, zu stark ihre an Rücksichtslosigkeit grenzende Beharrlichkeit. (Berliner Zeitung, 20.12.2005)

Disse strukturforskjellene fører til interessante forskjeller mellom tyske og norske avistekster. For det første vil norske avislesere nok i større grad enn tyske konfronteres med tolkningsproblemer. Det er oftere uklart hvem som er opphavet til en påstand eller et utsagn; jfr. Vadøy (2008:72) og Solfjeld (2009:243). Samtidig vil det også i tysk ved bruk av indikativ $\mathrm{i}$ indirekte tale oppstå tilsvarende ubestemt perspektiv i tyske tekster, om enn sjeldnere enn i norske: jfr. for eksempel den kursiverte setningen i følgende tekstutsnitt som vel kan oppfattes enten som en fortsettelse av referatet eller som forfatterens eget bidrag:

(31) Suckale sagte, weiter sei vorstellbar, dass der Konzern die Zulassung verändere. Zudem soll die Unternehmensberatung Kienbaum die Lohnstrukturen der Lokführer untersuchen und Vorschläge für Verbesserungen machen. (Süddeutsche Zeitung, 16.10.2007)

Det at man har konjunktiv som et alternativ i tysk, kan muligens ha den effekten at tyske lesere vil tendere til å tolke den kursiverte setningen i (31) som forfattertekst.

Samtidig synes de ulike strukturmulighetene i tysk og norsk å ha konsekvenser for hvilke strukturer norske og tyske journalister overhodet velger i sine tekster. I norske avistekster er direkte tale vanligere enn i tyske. Jfr. undersøkelsene i Vadøy (2008:68) og Solfjeld (2009:239-240), hvor det påvises en hyppigere bruk av direkte tale i norske avistekster i enn i tyske. I norske avistekster vil leserne dermed forholdsvis ofte støte på 
strukturer som i tekstutsnittene (32) og (33). Sitatet innledes med en tankestrek, omfatter ofte flere setninger og avsluttes med et utsagnsverb samt et subjekt som angir kilden.

(32) - Nav er blitt en jungel av tiltak. Nå står folk i ventekø mellom 40 og 50 ulike tiltak i Nav. Selv de som organiserer tiltak, sier det er vanskelig å forstå. Vi må forenkle hele Navsystemet, sier Dåvøy (Krf). (Aftenposten 29.05.2013)

(33) - Vi kan bare løse store globale problemer sammen. Nå snakker vi mye om Iran og kjernekraftproblemet og om Kosovo, sa Merkel. - Vi kan være uenige og fortsatt komme godt overens. Vi bør ikke feie problemer under teppet, vi bør legge dem på bordet, fortsatte hun. (Dagsavisen 16.10.2007)

Strukturene i (32) og (33) gir entydig informasjon om hvem de gjengitte utsagnene stammer fra. Spesielt i tilfeller hvor det er ikke-norske kilder, kan man likevel spørre seg om i hvilken grad disse strukturene faktisk kan eller skal oppfattes som direkte tale sitater. Man kan for eksempel tenke seg en nokså lang vei fra et tysk utsagn kanskje via engelsk oversettelse til en norsk muligens forkortet versjon som skal passes inn i en avistekst. Forandringene fra de opprinnelige formuleringene kan sikkert bli betydelige, selv om formen egentlig tilsier en relativt direkte gjengivelse.

For tyskkyndige på relativt høyt nivå er kunnskap om disse ulike aspektene ved referater i avisspråk viktig. Det er nødvendig å kunne reflektere omkring ubestemt perspektiv, som foreligger forholdsvis ofte i norsk, men som også forekommer i tysk ved bruk av indikativ. For eksempel bør kunnskap om ubestemt perspektiv absolutt inngå i undervisning som leder fram til profesjonell oversettervirksomhet hvor man oversetter fra norsk til tysk eller omvendt. Ved ulike tolkningsmuligheter i en norsk tekst som skal oversettes til tysk, vil det være aktuelt å vurdere om konteksten gir holdepunkter for den ene eller den andre tolkningen, noe som igjen vil være relevant for eventuelt valg av konjunktiv i en tysk gjengivelse. Ved oversettelse fra tysk til norsk kan det for eksempel være aktuelt å vurdere om man skal bygge inn uttrykk som kompenserer for at man i norsk ikke kan markere referat entydig i selvstendige setninger ved hjelp av konjunktiv. Man kan gjenta uttrykk som sier $a$, hevdet $b$, eller man kan bygge inn adverb som visst, angivelig eller lignende. Om dette temaet se Solfjeld (2009). Videre vil kunnskap om konvensjonene for referater i avistekster, som trolig også gjelder for sakprosatekster mer generelt, være viktig å formidle i undervisning for profesjonelle som skal oversette mellom tysk og norsk. Kunnskap om slike konvensjoner er nødvendig for å kunne oversette avistekster og andre sakprosatekster adekvat mellom de to språkene. Se Hansen og Colliander (2006) om tllsvarende tematikk i forbindelse med oversettelse mellom dansk og tysk.

\section{Avsluttende bemerkninger}

Hovedhensikten med denne artikkelen var å gi idéer til hva som kan og bør tas opp i undervisning omkring emnet referat av tale og tanker i tysk på høyere nivåer. Det er selvsagt en rekke temaer som ikke er blitt diskutert, for eksempel 'würde'-former i indirekte tale, eller i hvilken grad indikativ formidler at den refererende også står inne for påstandene som gjengis. Heller ikke er det store repertoaret av ulike alternative måter å uttrykke referat på - for eksempel ved hjelp av adverb som angeblich eller ved epistemisk bruk av modalverb (se Letnes 2002) - blitt diskutert. For velfunderte og oppdaterte framstillinger av 
emnet referat og indirekte tale i tysk se Fabricius-Hansen (2009:523-537) og Zifonun et al. (1997:1753-1787). Det er i seg selv et poeng at tyskstuderende som skal bli lærere i norsk skole, har kjennskap til de mange variantene av tempus-/modusformer som faktisk forekommer i tysk indirekte tale i vid forstand, og dermed unngår å være altfor normative i møte med det mangfoldet av former som sikkert dukker opp når norske elever produserer indirekte tale på tysk. Dette forutsetter at de som underviser i tysk språk ved høgskoler og universiteter, i tillegg til oppdatert kunnskap omkring konjunktiv i referater, har overblikk over indikativ i både protoypisk og ikke-protoypisk indirekte tale: bl.a. hvordan indikativformer kan tolkes temporalt, innenfor hvilke genrer indikativ vanligvis brukes, hvilket stilnivå indikativ formidler, og hvordan indikativ i tysk til tider kan åpne for ubestemt perspektiv, slik man ofte ser i norsk indirekte tale. Det er et komplisert bilde hvor underviseren ofte ikke vil kunne peke på helt klare linjer. Underviserens hovedoppgave vil derfor snarere bli å sensibilisere tyskstudenter overfor det komplekse samspillet av former og funksjoner som referater i tysk oppviser.

\section{Kildelitteratur}

Aftenposten 29.5.2013

Berliner Zeitung, 20.12.2005

Dagsavisen 16.10.2007

Dagsavisen 29.02.2008

Das Digitale Wörterbuch der deutschen Sprache (DWDS); http://www.dwds.de (aviskorpus, som består av utgaver av Berliner Zeitung, Zeit/Zeit online, Potsdamer neueste Nachrichten og Der Tagesspiegel)

Hackl, Erich (1987): Auroras Anlass. Erzählung. Zürich: Diogenes, 7-77. Norsk oversettelse av Lasse Tømte (1988): Auroras motiv. Oslo, Cappelen, 7-71. Holmås, Stig (1985): Tordensønnen, Oslo: Gyldendal. Tysk oversettelse av Lothar Schneider (1988): Donnersohn. Stuttgart/Wien: K. Thienemanns Verlag. Lenz, Siegfried (1978): Heimatmuseum. Hamburg: Hoffmann und Campe.

Stettbacher, Konrad J. (1990): Wenn Leiden einen Sinn haben soll. Hamburg: Hoffmann und Campe. Norsk oversettelse av Per Qvale (1993): Hvis lidelse skal ha en mening. Oslo: Gyldendal.

Süddeutsche Zeitung, 16.10.2007

\section{Litteratur}

Andersson, Sven-Gunnar (1994): Zum Indikativ in eingeleiteten Nebensätzen der indirekten Rede nach präteritalem Anführungsausdruck. I: Nordlyd 22, 38-52.

Ek, Britt-Marie (1996): Das deutsche Präsens. Tempus der Nichtvergangenheit (Lunder germanistische Forschungen 59). Lund: Almqvist \& Wiksell.

Fabricius-Hansen, Cathrine (1989): Tempus im indirekten Referat. I: Abraham, Werner og Theo Janssen (red.): Tempus - Aspekt - Modus (Linguistische Arbeiten 237). Tübingen: Niemeyer, 155-182.

Fabricius-Hansen, Cathrine (2002): Nicht-direktes Referat im Deutschen - Typologie und Abgrenzungsprobleme. I: Fabricius-Hansen, Cathrine, Oddleif Leirbukt og Ole Letnes (red.): Modus, Modalverben, Modalpartikeln. Trier: Wissenschaftlicher Verlag, 6-29. 
Fabricius-Hansen, Cathrine (2003): Wessen Redehintergrund? Indirektheitskontexte aus kontrastiver Sicht (Deutsch - Norwegisch - Englisch)". I: Leirbukt, Oddleif (red.):

Tempus/Temporalität und Modus/Modalität im Deutschen - auch aus kontrastiver Perspektive. Tübingen: Stauffenberg. 119-155.

Fabricius-Hansen, Cathrine (2009): Das Verb. I: Duden - Die Grammatik. Band 4 Mannheim/Leipzig/Wien/Zürich: Dudenverlag, 389-568.

Faarlund, Jan Terje, Svein Lie og Kjell Ivar Vannebo, (1997): Norsk referansegrammatikk. Oslo: Universitetsforlaget.

Hansen, Doris og Peter Colliander (2006): Zur Wiedergabe direkter und indirekter Rede. Eine Studie zur Übersetzungswissenschaft am Beispiel Deutsch-Dänisch und v.v. I: Colliander, Peter og Doris Hansen (red.): Übersetzer und Übersetzungkulturen (Translinguae 1). München: Meidenbauer, 67-90.

Kaufmann, Gerhard (1976): Die indirekte Rede und mit ihr konkurrierende Formen der Redeerwähnung. München: Hueber.

Letnes, Ole (2002): Zum Bezug epistemischer Modalität in der Redewiedegabe. I: Fabricius-Hansen, Cathrine, Oddleif Leirbukt og Ole Letnes (red.): Modus, Modalverben, Modalpartikeln. Trier: Wissenschaftlicher Verlag, 85-100.

Pütz, Herbert (1989): Referat - vor allem Berichtete Rede - im Deutschen und Norwegischen. I: Abraham, Werner og Theo Jansen (red.): Tempus - Aspekt - Modus (Linguistische Arbeiten 237). Tübingen: Niemeyer, 183-223.

Roncador, Manfred von (1988): Zwischen direkter und indirekter Rede. Nichtwörtliche direkte Rede, erlebte Rede, logophorische Konstruktionen und Verwandtes (Linguistische Arbeiten 192). Tübingen: Niemeyer.

Solfjeld, Kåre (1983): Indikativ in der indirekten Rede - Ein Vergleich DeutschNorwegisch. I: Zielsprache Deutsch 1, 41-47.

Solfjeld, Kåre (1989): Indikativ in der indirekten Rede. Strukturvergleich DeutschNorwegisch (Deutsch im Kontrast 9). Heidelberg: Groos.

Solfjeld, Kåre (2009): Redewiedergabe in verschiedener Form. Ein Vergleich DeutschNorwegisch". I: Hermes 43, 219-250

Solfjeld, Kåre (2012): Indikativ in deutscher indirekter Rede - die Perspektive des Fremdsprachenunterrichts. I: Deutsch als Fremdsprache 49/4, 209-217

Vadøy, Kathrine Antonsen (2008): Sprachen im Kontrast: Redewiedergabe und perspektvische Unbestimmtheit in deutschen und norwegischen Pressetexten. Masterarbeit, Oslo: Universität Oslo.

Zifonun, Gisela, Ludger Hoffmann og Bruno Strecker (1997): Grammatik der deutschen Sprache. Berlin: de Gruyter. 
